\title{
Biological marker indicators of paleo-depositional environment for the Eocene formations around Zara-Bolucan region (central anatolia, Turkey)
}

\author{
Nazan Yalçin Erik* \\ Department of Geological Engineering, Cumhuriyet University, Sivas 58140, Turkey
}

(Received May 8, 2018; revised May 28, 2018; accepted May 29, 2018; available online June 2, 2018)

\section{Citation:}

Yalçin Erik, N. Biological marker indicators of paleo-depositional environment for the Eocene formations around Zara-Bolucan region (central anatolia, Turkey). Advances in

Geo-Energy Research, 2018, 2(3):

237-244, doi: 10.26804/ager.2018.03.02.

Corresponding author:

*E-mail: nyalcin@gmail.com

\section{Keywords:}

Sivas Basin

organic geochemistry

biomarkers

Zara

Eocene

paleo-environment

\begin{abstract}
:
Biological marker (biomarker) characteristics and paleo-depositional conditions of Eocene sediments around Zara-Bolucan northeast of Sivas Basin have been determined by means of detail organic geochemical studies such as gas chromatography and gas chromatographymass spectrometry analysis. In the investigated area, northeast section of the Sivas Basin, the Eocene Bozbel and Kozluca Formations consist of a organic matter rich sedimentary rocks deposited within trangressive-regressive cycles. During the evaluation of paleoenvironment characteristics with biomarker data, data related to n-alkanes, isoprenoids, terpenoids and steroids were used. Especially, the marine environment features indicated by $C_{23}$ tricyclic/ $C_{30}$ hopane, the $C_{26} / C_{25}$ tricyclic terpanes, homohopane/ $C_{30}$ hopane and diasterane/regular sterane data. The ratios of $\mathrm{Pr} / \mathrm{Ph}, \mathrm{Pr} / \mathrm{n}-\mathrm{C}_{17}$ and $\mathrm{Ph} / \mathrm{n}-\mathrm{C}_{18}$ indicate that there is marine organic matter predominantly precipitated under reducing environmental conditions. In the studied samples, the algal-bacterial organic matter contribution was interpreted to be due to the superiority of the $\mathrm{C}_{23}$ tricyclic terpene to $\mathrm{C}_{24}$, as well as larger than the $\mathrm{C}_{24}$ tricyclic terpane. However, the gammacerane index suggests that there is initially a low salinity environment. The significant terrestrial organic matter contribution is indicated by the isoprenoid and biomarker ratios, dominance of higher $n$-alkanes such as $n-C_{29}, n-C_{31}$, CPI, TAR values, $n-C_{19} / n-C_{31}$, relative abundance of $C_{27}-C_{28}-C_{29}$ regular steranes. Suboxic to anoxic palo-depositional conditions are confired by the isoprenoid and n-alkane ratios and $\mathrm{T}_{\mathrm{m}} / \mathrm{T}_{\mathrm{s}}, \mathrm{C}_{29} \mathrm{~T}_{\mathrm{s}} / \mathrm{C}_{29}$ hopane ratios.
\end{abstract}

\section{Introduction}

There is a constantly growing need for fossil fuels in the world, which is often provided by sources such as oil, natural gas and coal. Many different methods are used to exploration these types of sources, and organic geochemical methods are vital for hydrocarbon investigation. Today's exploitation and production can be especially helpful in increasing the prediction efficiency of organic geochemistry as decreasing petroleum reserves and the lack of potential fields become increasingly difficult. Turkey also is one of the world's countries with the limited amount of fossil fuel reserves as many countries. In particular, oil reserves are limited to Southeast Anatolia and gas reserves are limited to those in the Thrace Basin. For this reason, the search for new resources of the country and the studies related to it continue with different perspectives. The study area is located in the Sivas Basin in the northeast section, it is one of the major sedimentary basins in Turkey (Fig. 1(a)) (Görür et al., 1998). In this basin, the sediments range from Upper Cretaceous to Pliocene in age, their thickness is very variable, and may reach up to 8,000 $\mathrm{m}$ (Kurtman, 1973) and the basin fill is mostly composed of fine-grained sediments such as shales and limestones. The basement is composed of metamorphics which outcrop in the northwestern part of the basin and an ophiolitic complex to the south (Kurtman, 1973; Görür et al., 1998; Özçelik, 2000).

The basin developed unconformably over the PaleozoicMesozoic basement and Eocene-Oligocene sediments (Figs. 1(b) and 1(c)). It is one of the sedimentological, tectonic and hydrocarbons-related basins that have been used for various geological (stratigraphic, paleontological, tectonic) researches (Artan and Sestini, 1971; Gökçen, 1981; İlleez et al., 1990; Korkmaz, 1990; Özçelik and Altunsoy, 1992; Altunsoy and Özçelik, 1995; Özçelik and Altunsoy, 1996; Ocakoğlu, 2001; Çiner et al., 2002; Yılmaz and Yılmaz, 2006; Yalçin Erik et al., 2015).

In particular, the main reason for the investigation of the Eocene units is to determine the levels of medium to 


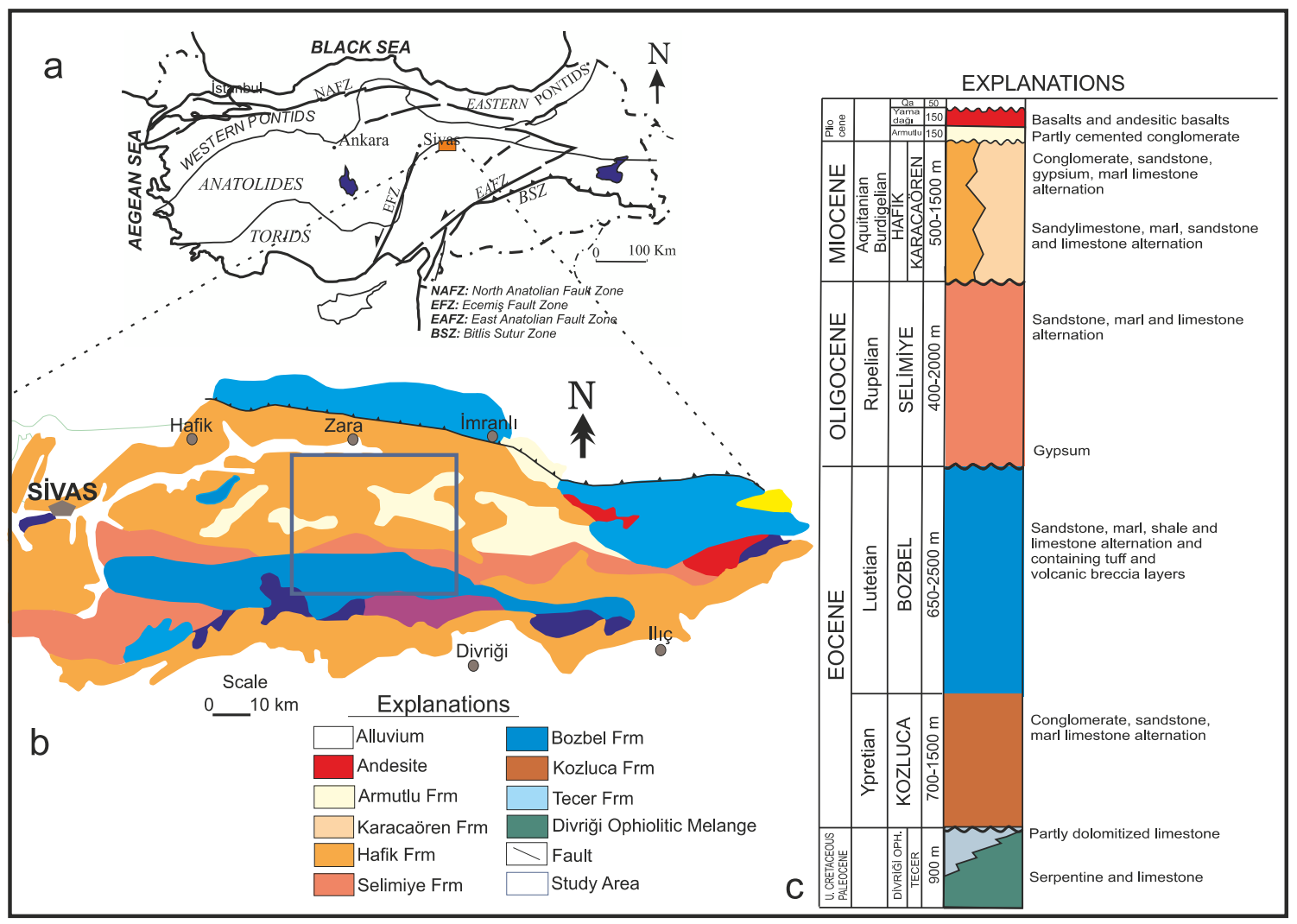

Fig. 1. Location map, simplified geological map and stratigraphic section of the study area Özçelik (2000).

high organic matter content (wt $\%$ TOC $>1$ ) and suitable type of kerogen for hydrocarbon generation (Type II/III mixture) within the basin, especially in Bozbel formation (İlleez et al., 1990; Korkmaz, 1990; Altunsoy and Özçelik, 1995; Özçelik and Altunsoy, 1996; Özçelik, 2000; Yalçın Erik et al., 2015). For this reason, it was aimed to determine the paleo depositional environment characteristics of the Eocene units related to hydrocarbon exploration by using detailed organic geochemical evaluations around Zara-Bolucan region.

\section{Geological setting}

The development on the northern margin of the Sivas basin started with the ophiolitic complex of the Upper PaleoceneMiddle Eocene units and it was stated that these include fandelta conglomerates, volcanics, nummulite-bearing limestones and marls. The Eocene aged rocks of Sivas Basin are represented by thick olistostromes, turbidites and volcanoclastics (Artan and Sestini, 1971; Kurtman, 1973; Gökten, 1993; İnan, 1993; Guezou et al., 1996; Poisson et al., 1996; Özçelik, 2000). Oligocene units overlying the Eocene sediments consist of thick gypsum, siltstones and sandstones (Temiz, 1996). A widespread marine sedimentation process (except the western part of the Sivas-Tecer Mountain line) was observed in the basin at the beginning of Upper Oligocene (?)-Lower Miocene (Dizer, 1962; Kurtman, 1973; Poisson et al., 1996; Temiz, 1996). The Lower Miocene shallow sea sediments represented by reefal limestones and marls pass upward to the Middle Miocene red clastics and unconformably over the middle and eastern parts of the basin (Temiz, 1996). The last sedimentary process of the basin and the elevation of the region are represented by Middle Miocene terrestrial- lagoonal sediments. The Pliocene aged conglomerate and sandstone strata were unconformably overlain by Miocene gypsiferous series. Also, quaternary alluviums and travertines are found in some parts of the basin (Kurtman, 1973) (Fig. 1(b)). The general stratigraphic section of the basin is given in Fig. 1c. The Kozluca formation, which is one of the Eocene aged units, has been formed by alternation of fine shales, marls, sandstones and clayey limestones, and it is Ipresian aged. The formation is overlain by tuffite layers belonging to Bozbel Formation. Lithological features and fossil content indicate that this formation has been deposited in the deep sea conditions (Kurtman, 1973). The Bozbel formation, composed of marl, sandstone, shale, limestone and marly limestone alternations, indicates the marine sedimentary environment and Ypresian age.

\section{Material and methods}

Thirty-five organic rich shale, mudstone and carbonaceous shale outcrop samples of Eocene units were collected from around Zara-Bolucan region. A systematic and detailed sampling guideline was carried out based on lithological change in vertical and lateral of the Eocene sediments on two measured columnar sections in the study area. Some shale and carbona- 
Table 1. Some n-alkane and isoprenoid ratios and calculated parameters for the studied samples.

\begin{tabular}{llllll}
\hline Determined Parameters & ZB-1 & ZB-2 & ZB-3 & ZB-4 & ZB-5 \\
\hline $\mathrm{Pr} / \mathrm{Ph}$ ratio & 0.59 & 0.52 & 0.54 & 0.63 & 0.82 \\
$\mathrm{Pr} / \mathrm{nC}_{17}$ & 0.41 & 0.36 & 0.45 & 0.46 & 0.38 \\
$\mathrm{Ph} / \mathrm{nC}_{18}$ & 0.43 & 0.35 & 0.44 & 0.45 & 0.36 \\
$\mathrm{CPI}_{25-33}$ & 1.07 & 1.07 & 1.09 & 1.02 & 1.14 \\
$\mathrm{OEP}_{25-33}$ & 1.07 & 1.13 & 1.08 & 1.03 & 1.14 \\
$\mathrm{nC}_{19} / \mathrm{nC}_{31}$ & 0.95 & 1.06 & 0.85 & 0.14 & 1.01 \\
$\mathrm{nC}_{24}+\mathrm{nC} 24-$ & 1.37 & 1.64 & 1.39 & 4.05 & 1.33 \\
$\mathrm{TAR}$ & 1.75 & 2.44 & 1.86 & 9.02 & 1.28 \\
Extract (mg/kg rock) & 29 & 112 & 68 & & 76 \\
\hline
\end{tabular}

ceous shale samples $(>0.5$ TOC, wt. \%) were applied with solvent extraction liquid chromatography gas chromatography (GC) and gas chromatography-mass spectrometry (GC-MS) analyses were done on bulk extracts obtained from five samples. The aliphatic components obtained by chromatographic fractionation were done according to ASTM (D 5307-97, 2002) by Agilent 6850 instrument. Sterane and terpane ratios were compute by integration of peak highs from the $\mathrm{m} / \mathrm{z} 217$, $\mathrm{m} / \mathrm{z} 191$ mass fragmentograms, n-alkanes and acyclic isoprenoids were describe from fragmentation ion $\mathrm{m} / \mathrm{z} 85$ and the biomarker ratios were calculated by measuring peak heights in the fragmentograms. Biomarker analyses were done in the research laboratories of the Turkish Petroleum Corporation (TP Research Group, Ankara).

\section{Results and discussions}

\subsection{Molecular geochemistry of organic matter}

In this context, the quantity of extractable organic matter (EOM), saturated, aromatic fractions and hetero atomic (NSO) compound ratios of the samples have been determined. The extractable organic matter ratios of the investigated samples range from 29 to $141 \mathrm{mg} / \mathrm{kg}$ rock (Table 1). The aliphatic fractions and hetero atomic components are varies between $36 \%$ to $81 \%$ and $12 \%$ to $52 \%$, respectively, while aromatic fractions range from $6 \%$ to $27 \%$.

\subsubsection{N-Alkanes, acyclic isoprenoids}

The gas chromatography (GC) analysis has been used to determine paleo-environmental conditions of Eocene Bozbel and Kozluca Formation based on the distribution of n-alkanes and acyclic isoprenoids. These compound properties are very similar to each other in the investigated samples. n-alkane distribution of the studied samples comprise mainly from $\mathrm{n}-\mathrm{C}_{12}$ to $\mathrm{n}-\mathrm{C}_{35}$. Table 1 summarizes the results and some calculated parameters of isoprenoids and n-alkanes. Oddeven carbon number predominance (OEP) values and carbon preference index (CPI) values of the Eocene samples ranging from 1.03 to 1.14 and 1.02 to 1.14 , respectively.

The long chain n-alkanes $\left(n-C_{25}-n-C_{35}\right)$ in the compo- sitions of the studied samples are more in proportion to the mid-chain $\left(\mathrm{C}_{21}-\mathrm{C}_{25}\right)$ n-alkanes. In this composition, $\mathrm{C}_{27}$, $\mathrm{C}_{29}$ and $\mathrm{C}_{31}$ being the most important components. Also, the terrigenous/aquatic ratio (TAR) is the ratio between the concentration of long-chain n-alkanes mostly derived from terrestrial plants $\left(>n-C_{27}\right)$ to short chain n-alkanes of algal origin $\left(<\mathrm{n}-\mathrm{C}_{15}\right)$, and it is used to evaluate the importance of terrigenous versus aquatic inputs. The calculated $n-C_{19} / n-C_{31}$ ratios vary between 0.85 and 1.06 , while, the $n-C_{24}+/ n-C_{24}-$ ratios are high $(>1)$ and TAR is more than 1 and range between 1.28 to 9.02 . This wide range of values suggests various source organic matter inputs, from terrestrial to marine. This results support by predominance of $\mathrm{C}_{27}, \mathrm{C}_{29}$ and $\mathrm{C}_{31} \mathrm{n}$ alkanes (Peters and Moldowan, 1993; Peters et al., 2005).

Furthermore, the determined samples have acyclic isoprenoids (pristane and phytane). Phytane $(\mathrm{Ph})$ is higher than pristine $(\mathrm{Pr})$, therefore the $\mathrm{Pr} / \mathrm{Ph}$ ratios range from 0.52 to 0.82 (Table 1). Additionally, acyclic isoprenoid ratios were calculated as $\mathrm{Pr} / \mathrm{n}-\mathrm{C}_{17}$ and $\mathrm{Ph} / \mathrm{n}-\mathrm{C}_{18}$ ratios compared to $\mathrm{n}$ alkanes and values range between 0.36 to 0.46 and $0.35-0.45$, respectively (Table 1) and indicate to anaerobic environment conditions (Tissot and Welte, 1984; Peters et al., 2005). In this respect, all of the analyzed samples have $\mathrm{Pr} / \mathrm{Ph}$ ratios of $<1$ and usually close to 1 CPI values (1.02-1.14) define algal/bacterial organic matter, which is typical of marine depositional conditions that indicate sedimentation under reducing conditions (Tissot and Welte, 1984).

\subsubsection{Terpanes and steranes}

The detailed biomarker properties and some calculated ratios as a result of organic geochemical evaluations are given in Table 2. $\mathrm{C}_{24}$ tetracyclicterpane, $\mathrm{C}_{23}$ tricyclic terpanes, $\mathrm{C}_{29}$ hopane, $\mathrm{C}_{30}$ hopan, $\mathrm{C}_{27}$ sterane, $\mathrm{C}_{29}$ sterane are considerable components (Figs. 2(a) and 2(b)).

Especially, the terpanes are prominent saturated cyclic triterpenoid components of the Eocene sediments in the investigated area. The pentacyclic triterpanes are represented in the present study by the hopanes and the homohopanes (Fig. 2(a)). In this study hopane $\left(\mathrm{C}_{30} 17 \alpha(\mathrm{H})\right.$-hopane), norhopane $\left(\mathrm{C}_{29} 17 \alpha(\mathrm{H})\right.$-hopane $), \mathrm{C}_{31} 17 \alpha(\mathrm{H})$-hopane, moretane $\left(\mathrm{C}_{30}\right)$, normoretane $\left(\mathrm{C}_{29}\right), 18 \alpha(\mathrm{H})$-trisnorhopane $\left(\mathrm{T}_{\mathrm{s}}\right)$, and 


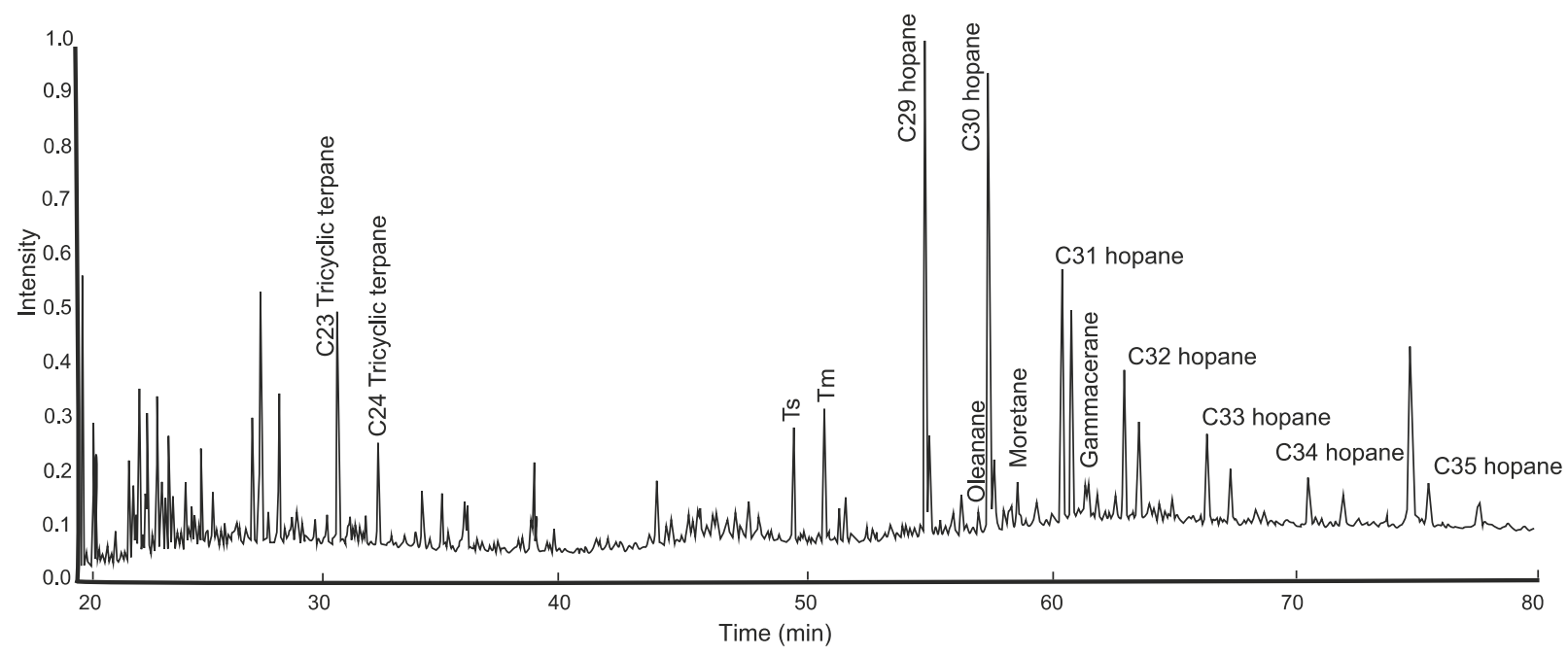

(a)

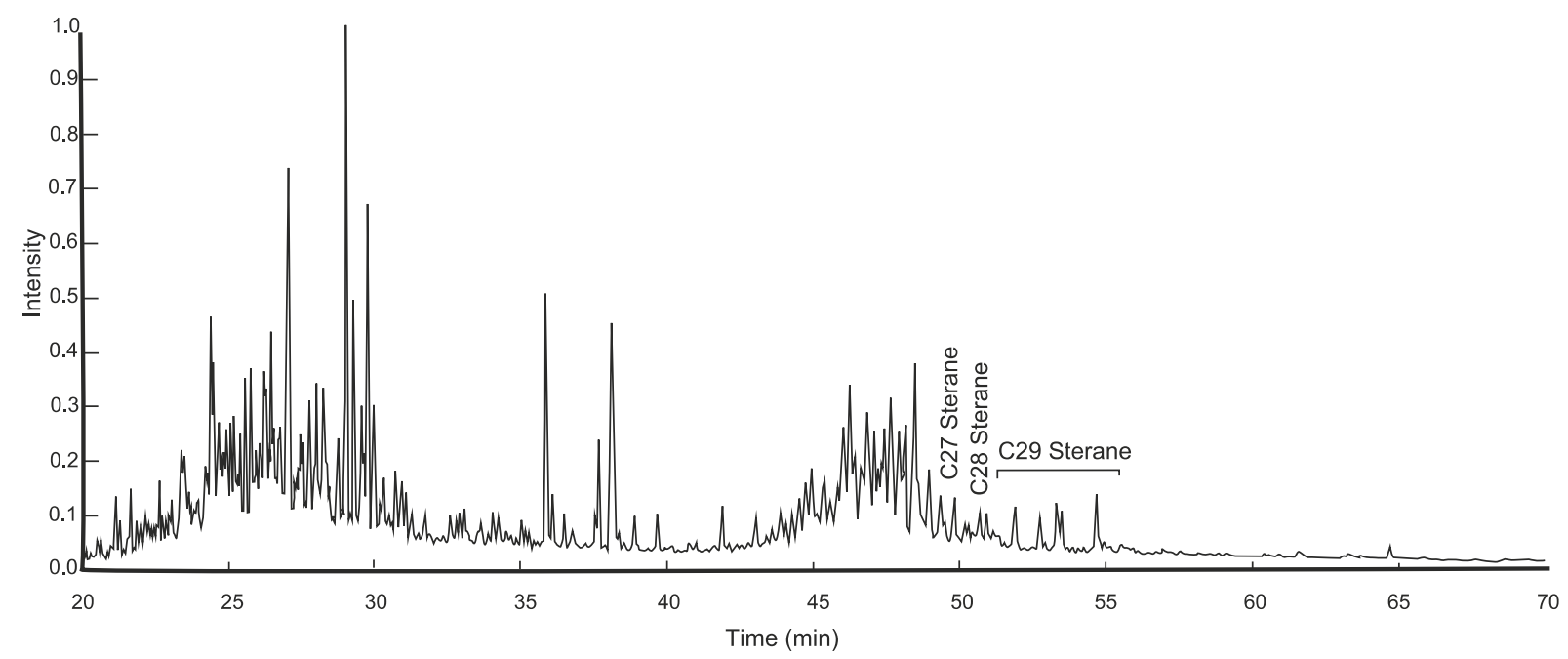

(b)

Fig. 2. a) $\mathrm{m} / \mathrm{z} 191$ and b) $\mathrm{m} / \mathrm{z} 217$ chromatograms of the investigated samples (ZB-2).

$17 \alpha(\mathrm{H})$-trisnorhopane $\left(\mathrm{T}_{\mathrm{m}}\right)$ components were determined and assessments related to the paleo-environmental interpretation were made.

$\mathrm{C}_{23}$ tricyclic terpanes were determined in the investigated samples and (Fig. 2a) have relatively high $\mathrm{C}_{23}$ tricyclic terpane ratios (1.39-2.76) (Table 2). Also, the ratio of $\mathrm{C}_{24}$ tetracyclic terpane relative to $\mathrm{C}_{23}$ triterpanes vary according to organofacies characteristics, with comparatively high ratios in source rocks with terrestrial organic matter input (Peters and Moldowan, 1993). In the terpane distribution ( $\mathrm{m} / \mathrm{z} \mathrm{191)}$, the dominantly algal-bacterial organic matter contribution for the extracts can be suggested from the $\mathrm{C}_{19}-\mathrm{C}_{25}$ tricyclic terpanes distribution by the dominance of $\mathrm{C}_{23}$ tricyclic terpane relative over the $\mathrm{C}_{23}$ tricyclic terpane greater than $\mathrm{C}_{24}$ tricyclic terpane $(>1)$. However, $\mathrm{C}_{26} / \mathrm{C}_{25}$ tricyclic terpane ratios generally low (0.29-0.55).

In the pentacyclic terpanes, the high $\mathrm{C}_{24}$ tetracyclic/ $\mathrm{C}_{26}$ tricyclics ratio, the moderate-high norhopane/hopane ratio, and the moderate to high $\mathrm{C}_{35} / \mathrm{C}_{34}$ hopane ratio (Table 2) indicate marine carbonate facies and anoxic depositional condition for the Bozbel and Kozluca Formation samples.

The $T_{s} /\left(T_{s}+T_{m}\right)$ ratio is range between 0.44 to 0.49 , with a mean value of 0.44 and indicating that $T_{m}$ is the dominant component of investigated samples. The $T_{m} / T_{s}$ ratio change between 1.14 and 1.41 , in the meanwhile the $\mathrm{C}_{32} \mathrm{~S} /(\mathrm{S}+\mathrm{R})$ ratio is varies between 0.51 and 0.56 . While, the diasterane index is ranging from 0.36 to 0.91 , the tricyclic/hopane ratio is low, like the $\mathrm{C}_{24}$ tetracyclic terpane/ $\mathrm{C}_{26}$ tricyclic terpane and the $\mathrm{C}_{26} / \mathrm{C}_{25}$ tricyclic terpane ratios (Table 2).

The relative abundances of the $\mathrm{C}_{27}$-cholestane, $\mathrm{C}_{28}$ ergostane and $\mathrm{C}_{29}$ stigmastane have been evaluated from $\mathrm{m} / \mathrm{z}$ 217 chromatograms (Fig. 2(b)). The stigmastane is more common in most of the samples than the other regular sterane components, with a contribution of $31.7 \%-41.1 \%$, followed by cholestane (25.8\%-45.2\%), and ergostane (22.7\%-33.9\%). The compositional ratios of regular steranes $(\alpha \alpha \alpha 20 \mathrm{R})$ in 
Table 2. m/z 191 and 217 parameters of GC-MS data and some determined parameters for the investigated samples.

\begin{tabular}{|c|c|c|c|c|c|}
\hline \multirow{2}{*}{ Determined Parameters } & \multicolumn{5}{|c|}{ Sample Numbers } \\
\hline & ZB-1 & ZB-2 & ZB-3 & ZB-4 & ZB-5 \\
\hline $\mathrm{C}_{23}$ Tri.// $\mathrm{C}_{24}$ Tri. & 2.76 & 2.69 & 2.71 & 2.19 & 1.39 \\
\hline Norhopan/Hopan & 0.97 & 0.95 & 0.93 & 0.92 & 0.90 \\
\hline $\mathrm{C}_{31} \mathrm{R} / \mathrm{C}_{30}$ & 0.45 & 0.43 & 0.41 & 0.43 & 0.45 \\
\hline $\mathrm{C}_{26}$ Tri.// $\mathrm{C}_{25}$ Tri. & 0.29 & 0.49 & 0.41 & 0.53 & 0.55 \\
\hline $\mathrm{C}_{23}$ Tri/ $\mathrm{C}_{30}$ Hopan & 0.95 & 0.54 & 0.29 & 0.44 & 0.55 \\
\hline $\mathrm{C}_{24}$ Tet./C $\mathrm{C}_{26}$ Tri. & 5.59 & 2.21 & 3.37 & 3.28 & 2.24 \\
\hline Tri/Hop & 0.45 & 0.06 & 0.18 & 0.25 & 0.37 \\
\hline $\mathrm{C}_{35} / \mathrm{C}_{34}$ Homohopane & 1.63 & - & 1.27 & 2.18 & - \\
\hline $\mathrm{T}_{\mathrm{m}} / \mathrm{T}_{\mathrm{s}}$ & 1.14 & 1.21 & 1.36 & 1.31 & 1.41 \\
\hline $\mathrm{T}_{\mathrm{s}} / \mathrm{T}_{\mathrm{s}}+\mathrm{T}_{\mathrm{m}}$ & 0.49 & 0.48 & 0.45 & 0.46 & 0.44 \\
\hline $\mathrm{C}_{32} 22 \mathrm{~S} /(22 \mathrm{~S}+22 \mathrm{R})$ hopane & 0.56 & 0.54 & 0.54 & 0.51 & 0.56 \\
\hline $\mathrm{C}_{29} \beta \beta /(\beta \beta+\alpha \alpha)$ & 0.63 & 0.65 & 0.62 & 0.58 & 0.59 \\
\hline $\mathrm{C}_{27} / \mathrm{C}_{29}$ & 0.93 & 0.79 & 0.73 & 0.65 & 0.89 \\
\hline $\mathrm{C}_{28} / \mathrm{C}_{29}$ & 0.73 & 0.67 & 0.71 & 0.81 & 0.73 \\
\hline $\mathrm{C}_{27} / \mathrm{C}_{27}+\mathrm{C}_{29}$ & 0.45 & 0.41 & 0.40 & 0.39 & 0.47 \\
\hline Dia/Reg (Diasterane Index) & 0.91 & 0.54 & 0.46 & 0.36 & 0.58 \\
\hline
\end{tabular}

the examined samples is $\mathrm{C}_{29}>\mathrm{C}_{27}>\mathrm{C}_{28}$. The predominance of the stigmastane component concerns an intense terrestrial organic matter additive, whereas a dominance of cholestane and ergostane indicate a dominance of marine phytoplanktons and lacustrine algaes, respectively (Peters and Moldowan, 1993) (Fig. 3).

\subsection{Paleodepositional conditions}

Terpanes and steranes are the most important compounds that can give very specific information about the source and deposition environment of investigated organic matter rich levels (Peters et al., 2005). Biomarker ratios and indices of triterpanes and steranes of investigated samples are shown in Tables 1 and 2.

The $\mathrm{C}_{35} / \mathrm{C}_{34}$ homohopane and norhopane/ $\mathrm{C}_{30}$ hopanes $\left(\mathrm{C}_{29} \mathrm{H} / \mathrm{C}_{30} \mathrm{H}\right)$ values can be used to identified paleodepositional facies characteristics (Peters et al., 2005) and the moderate to high $\mathrm{C}_{35} / \mathrm{C}_{34}$ homohopane ratios indicates the anoxic conditions of the paleo depositional environment of Eocene sediments. The diasteranes/regular steranes ratio (diasterane index) for the analyzed samples show generally low (0.36-0.91) (Table 2) and they indicate carbonate rocks and anoxic depositional environment. The same conclusion can be reached by the dominance of $17 \alpha(\mathrm{H})-22,29,30-$ trisnorhopane $\left(\mathrm{T}_{\mathrm{m}}\right)$ over $18 \alpha(\mathrm{H})-22,29,30$-trisnorhopane $\left(\mathrm{T}_{\mathrm{s}}\right)$, as well as the high values of $\mathrm{C}_{24}$ tetracyclic/ $\mathrm{C}_{26}$ tricyclic terpan ratios (Tissot and Welte, 1984; Peters et al., 2005). Especially, $\mathrm{C}_{24} / \mathrm{C}_{26}$ terpane ratios are related with a mixed organic matter of algal, bacterial and abundant terrestrial sourced. Also, the $\mathrm{C}_{31} \mathrm{R}$ homohopane/ $\mathrm{C}_{30}$ hopane ratios $(>0.25)$ indicate that the Eocene sediments were deposited in a marine depositional

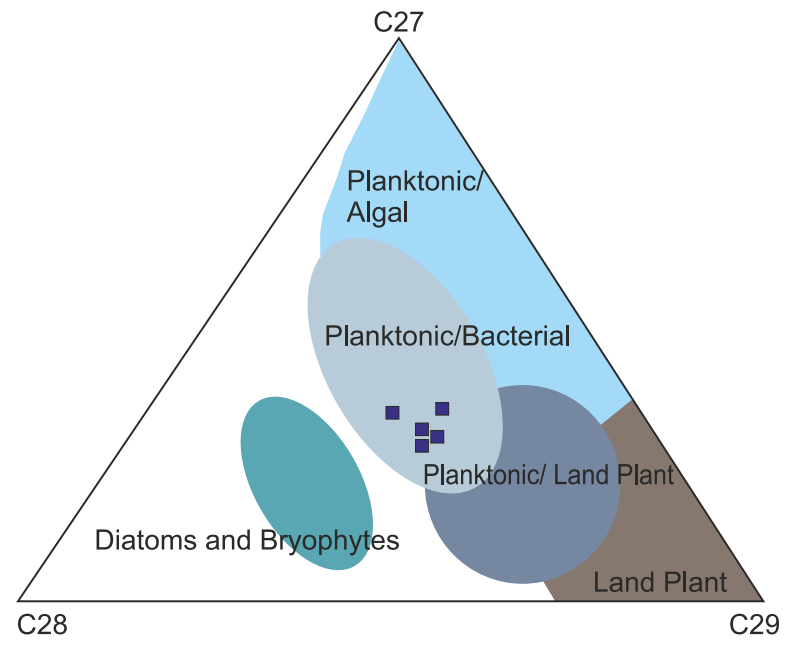

Fig. 3. Sterane ternary diagram of $\mathrm{C}_{27} \% \mathrm{C}_{28} \%$ and $\mathrm{C}_{29} \%(\alpha \alpha \alpha \mathrm{R})$ concerning the selected samples in Bozbel and Kozluca Formations.

environment (Figs. 4(a) and 4(b)). The $\mathrm{C}_{27}, \mathrm{C}_{28}$, and $\mathrm{C}_{29}$ regular sterane distributions imply that there are greater contributions from terrestrial higher plants than marine algae in the Bozbel and Kozluca Formations samples.

The ratios of the $\mathrm{Pr} / \mathrm{Ph}$ for the Eocene sediment extracts were generally low and ranged between 0.52 and 0.82 (Table 1) indicating anoxic, reduced marine carbonate depositional environment (Tissot and Welte, 1984; Peters et al., 2005). Also, the $\mathrm{Pr} / \mathrm{n}-\mathrm{C}_{17}$ ratios ranged between 0.36 and $0.46(<$ 0.5 ) indicating marine depositional environment. The cross plot of $\mathrm{Pr} / \mathrm{n}-\mathrm{C}_{17}$ versus $\mathrm{Ph} / \mathrm{n}-\mathrm{C}_{18}$ for the whole analyzed samples (Fig. 5(a)) shows mixed (marine and terrestrial) source organic matters deposited under reduced condition with a 


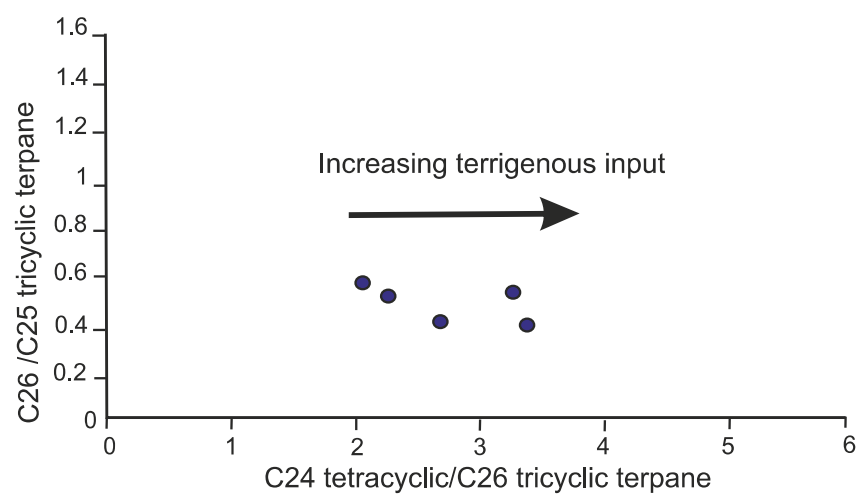

(a)

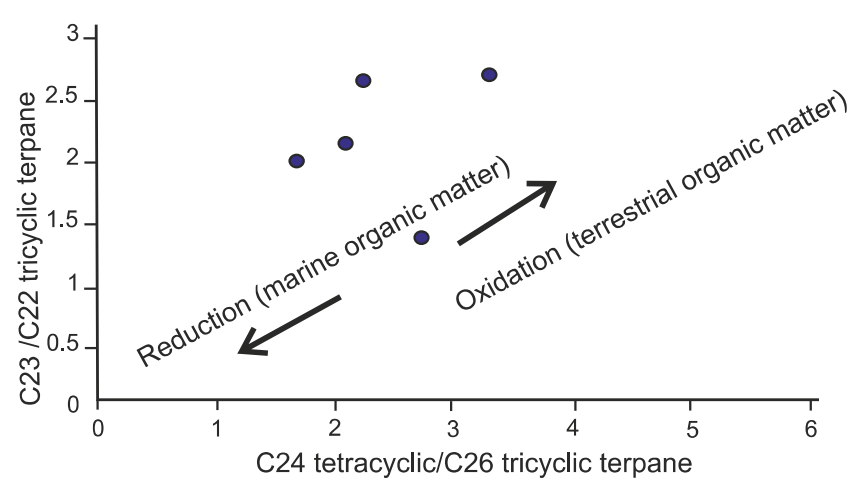

(b)

Fig. 4. a) Relationships between $C_{26} / C_{25}$ tricyclic terpane vs $C_{24}$ tetracyclic/ $C_{26}$ tricyclic terpane ratios, b) $C_{23} / C_{22}$ tricyclic terpane vs $C_{24}$ tetracyclic/ $C_{26}$ tricyclic terpane ratios for Eocene sediments.

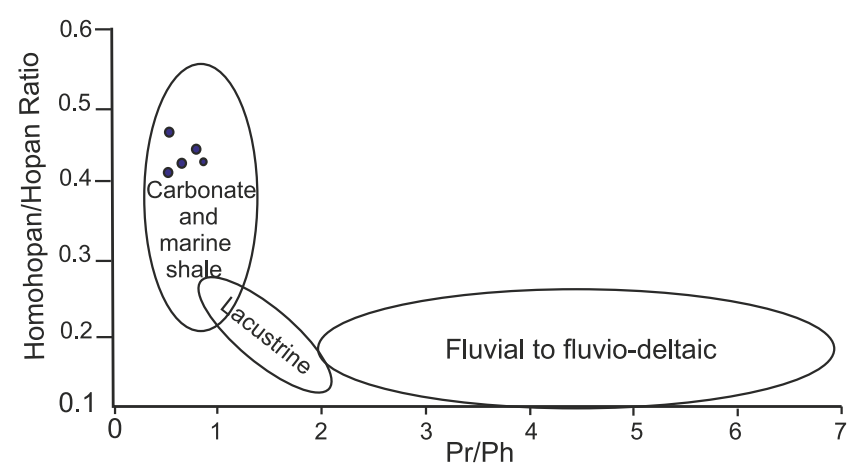

(a)

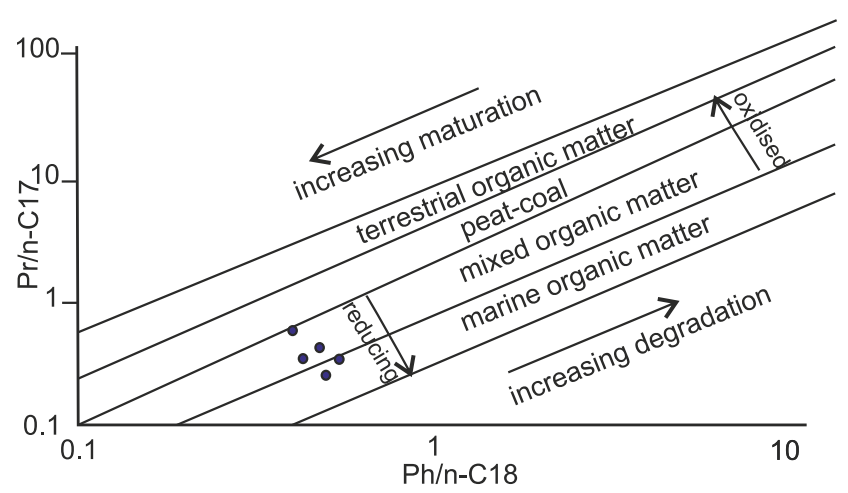

(b)

Fig. 5. Result of GC and GC-MS analysis data on diagrams; a) Homohopane/hopane ratio vs $\mathrm{Pr} / \mathrm{Ph}$ ratio, b) $\mathrm{Pr} / \mathrm{nC}_{17} \mathrm{vs} \mathrm{Ph} / \mathrm{nC}_{18}$ ratio for Eocene sediments.

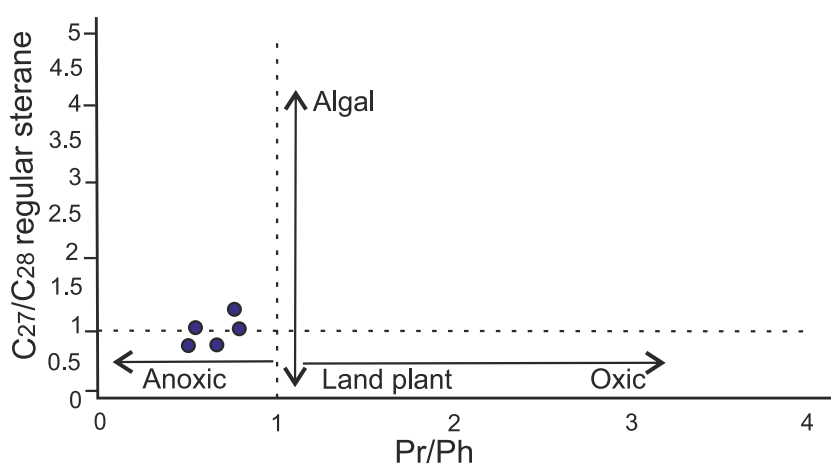

(a)

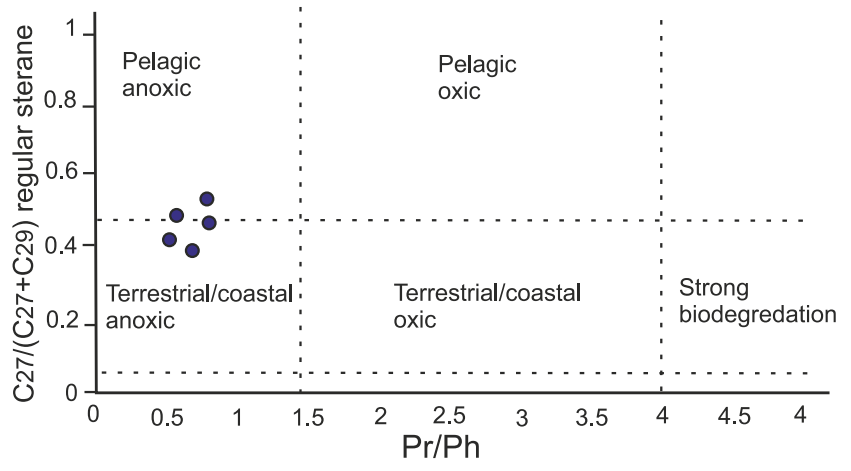

(b)

Fig. 6. Relationship between a) $C_{27} / C_{28}$ regular sterane vs $P r / P h$ ratios and b) $C_{27} /\left(C_{27}+C_{27}+C_{29}\right.$ regular sterane $)$ vs $P r / P h$ ratios for investigated samples. 
less effect of biodegradation. Additionally, the $\mathrm{Pr} / \mathrm{Ph}$ versus $\mathrm{C}_{31} \mathrm{R}$ homohopane/ $\mathrm{C}_{30}$ hopane diagram and $\mathrm{C}_{26} / \mathrm{C}_{25}$ tricyclic terpanes ratios $(<0.9)$ indicate a carbonate and marine shale (Fig. 5(b)) (Peters et al., 2005). This result supports the data is provided by the $\mathrm{C}_{27} / \mathrm{C}_{29} \alpha \alpha \alpha$ (20R) sterane ratio which rises from 0.65 to 0.93 and the $\mathrm{C}_{27} / \mathrm{C}_{27}+\mathrm{C}_{29}$ sterane ratio was 0.39 0.47 .

The majority of the analyzed samples show relatively high concentrations of $\mathrm{C}_{29}$ peaks with high norhopane/ $\mathrm{C}_{30}$ hopane ratios ranging from 0.90 to $0.97(>0.6)$ and $\mathrm{C}_{35} / \mathrm{C}_{34}$ values (> 0.8 ) indicate to a marine environment (Peters and Moldowan, 1993; Peters et al., 2005) with organic rich carbonates and evaporites (Peters et al., 2005). The extracts of the Eocene samples are characterized by the presence of a relatively low to moderate abundance $(0.36-0.91)$ of the re-arranged steranes (Table 2). This is a characteristic feature of an anoxic, clay poor, carbonate, marine depositional environment. Also, the identification of $\mathrm{C}_{30}$ steranes in all samples supports their derivation from marine source rocks (Peters and Moldowan, 1993) (Table 2). There is a positive correlation between $\mathrm{Pr} /(\mathrm{Pr}$ $+\mathrm{Ph})$ and $\mathrm{C}_{27}$ diasterane index that were controlled by the depositional environments. Plots of regular steranes $\mathrm{C}_{27} /\left(\mathrm{C}_{27}+\right.$ $\mathrm{C}_{29}$ ) versus $\mathrm{Pr} / \mathrm{Ph}$ ratio, and $\mathrm{C}_{27} / \mathrm{C}_{29}$ versus $\mathrm{Pr} / \mathrm{Ph}$ ratio provide important knowledge of organic matter rich rocks based on paleo depositional characteristics (Moldowan et al., 1991). According to these diagrams suggests a major contribution of terrigenous organic matter and a secondary input of aquatic microorganisms (Figs. 6(a) and 6(b)).

\section{Conclusions}

The Eocene shale, mudstone and carbonaceous shale samples of Bozbel and Kozluca Formations are exposed around Zara region and were analyzed for interpret the paleo depositional environment characteristics. Some of the remarkable features of the biomarker evaluations of the examined samples are; dominance of $\mathrm{T}_{\mathrm{m}}$ over $\mathrm{T}_{\mathrm{s}}$ and the ratios of diasterane/regular steranes, $\mathrm{C}_{24}$ tetracyclic terpane/ $\mathrm{C}_{23}$ tricyclic terpane, $\mathrm{C}_{24}$ tetracyclic terpane/ $\mathrm{C}_{26}$ tricyclic terpane and $\mathrm{C}_{29} / \mathrm{C}_{30}$ hopane. The detail biomarker parameters such as $\mathrm{Pr} / \mathrm{Ph}, \mathrm{n}-\mathrm{C}_{19} / \mathrm{n}-\mathrm{C}_{31}$, $\mathrm{n}-\mathrm{C}_{24}+/ \mathrm{n}-\mathrm{C}_{24^{-}}$ratios, OEP, CPI, $\mathrm{T}_{\mathrm{m}} / \mathrm{T}_{\mathrm{s}}$ ratio and high ratio of $\mathrm{C}_{29}$ regular steranes indicate that the organic matter is mostly sourced from terrestrial with a minor contribution from marine-influenced origin. Generally, the paleo-redox features of depositional environment are supported by the $\mathrm{T}_{\mathrm{m}} / \mathrm{T}_{\mathrm{s}}$ and $\mathrm{Pr} / \mathrm{n}-\mathrm{C}_{17}$ versus $\mathrm{Ph} / \mathrm{n}-\mathrm{C}_{18}$ diagram. The marine depositional environment conditions was supported by $\mathrm{C}_{26} / \mathrm{C}_{25}$ tricyclic terpanes, $\mathrm{C}_{23}$ tricyclic/ $\mathrm{C}_{30}$ hopane ratios and $\mathrm{C}_{31} \mathrm{R}$ homohopane/ $\mathrm{C}_{30}$ hopane ratios. Based on biomarker properties, it was interpreted that Eocene Kozluca and Bozbel formation were deposited in a marine environment and contained mixed aquatic and terrestrial organic matter. Also, there is no significant difference between the shales in the Bolucan and Kozluca formations for the analyzed samples.

\section{Acknowledgments}

This investigation was sponsored by the Cumhuriyet Uni- versity (CU), Scientific Projects Support Fund (CUBAP) under the Project No: M-291. The author would like to also thank anonymous referees and Prof. Jianchao Cai who constructively reviewed and improved the paper.

Open Access This article is distributed under the terms and conditions of the Creative Commons Attribution (CC BY-NC-ND) license, which permits unrestricted use, distribution, and reproduction in any medium, provided the original work is properly cited.

\section{References}

Altunsoy, M., Özçelik, O. Zara-İmranlı (Sivas) Güneyi Tersiyer Çökellerinin petrol Anakaya Özellikleri, Süleyman Demirel Üniversitesi Müh. Mim. Fak. Dergisi 1995, 8: $1-20$.

Artan, Ü., Sestini, G. Sivas-Zara-Beypınarı bölgesinin jeolojisi. MTA Dergisi 1971, 76: 80-98.

Çiner, A., Koşun, E., Peynoux, M. Fluvial, evaporitic and shallow-marine facies architecture, depositional evolution and cyclicity in the Sivas Basin (Lower to Middle Miocene), Central Turkey. J. Asian Earth Sci. 2002, 21(2): 147-165.

Dizer, A. Foraminifera of the Miocene of the Sivas Basin (Turkey). İ.Ü. Fen. Fak. Mec., Seri B. 1962, 27(1-2): 49-83.

Gökçen, S.L. Zara-Hafik Güneyindeki paleojen İstifinin sedimantolojisi ve paleocoğrafik Evrimi. Yerbilimleri 1981, 8: 1-21.

Gökten, E. Ulaş (Sivas) Doğusunun Sivas Havzası Kenarının Jeolojisi: İç Toros Okyanusunun Kapanımıyla ilgili Tektonik Gelişim. Bull. TPJD 1993, 5: 35-55.

Görür, N., Tüysüz, O., Şengör, A.M.C. Tectonic evolution of the Central Anatolian basins. Int. Geol. Rev. 1998, 40(9): 831-850.

Guezou, J.C., Temiz, H., Poisson, A., et al. Tectonics of the Sivas basin: The Neogene record of the Anatolian accretion along the inner Tauric suture. Int. Geol. Rev. 1996, 38(10): 901-925.

İlleez, H.İ., Soylu, C., Harput, O.B., et al. Tekman, Murat ve Sivas Baseni yüzey kesitlerinde bulunan birimlerin hidrokarbon türetme potansiyellerinin değerlendirmesi, TPAO Arşivi, Rap. No. 1040, 1990.

İnan, S. Structural Evolution of the Southeastern part of the Sivas Basin (central eastern Turkey), Bulletin of Faculty of Eng. Cumhuriyet Uni., Serie A, Earth Sci. 1993, 10: 13-22.

Korkmaz, S. Sivas havzasinda ana kaya fasiyesi ve petrol oluşumunun organik jeokimyasal yöntemlerle araştırılması. Jeoloji Mühendisliği 1990, 37: 61-68.

Kurtman, F. Sivas-Hafik-Zara ve İmranlı bölgesinin jeolojik ve tektonik yapısı. MTA Dergisi 1973, 80: 1-33.

Moldowan, J.M., Lee, C.Y., Watt, D.S., et al. Analysis and occurrence of $\mathrm{C}_{26}$-steranes in petroleum and source rocks. Geochim. Cosmochim. Acta 1991, 55(4): 1065-1081.

Ocakoğlu, F. Repetitive subtidal-to-coastal sabkha cycles from a Lower-Middle Miocene marine sequence, eastern Sivas Basin. Turkish J. Earth Sci. 2001, 10(1): 17-34.

Özçelik, O., Altunsoy, M. Bolucan (Zara-Sivas) yöresinde 
oligosen yaşlı selimiye formasyonu kumtaşlarının sedimanter petroloji incelemesi, Jeoloji Müh. Dergisi 1992, 41: 131-137.

Özçelik, O., Altunsoy, M. Clastic petrofacies, provenance and organic facies of the Bozbel Formation (Lutetian) in the Eastern Sivas Basin (Turkey). Mar. Pet. Geol. 1996, 13(5): 493-501.

Özçelik, O. Source rock Evaluation of Tertiary sediments in the Sivas Basin, Central Anatolia. Bulletin of Faculty Eng. Cumhuriyet Uni., Serie A, Earth Sci. 2000, 17(1): 31-44.

Peters, K.E., Moldowan, J.M. The Biomarker Guide: Interpreting Molecular Fossils in Petroleum and Ancient Sediment. New Jersey, United States, Prentice-Hall Inc, Englewood Cliffs, 1993.

Peters, K.E., Walters, C.C., Moldowan, J.M. Biomarkers and Isotopes in Petroleum Exploration and Earth History. Cambridge, UK, Cambridge University Press, 2005.
Poisson, A., Guezou, J.C., Öztürk, A., et al. Tectonic setting and evolution of the Sivas Basin, Central Anatolia, Turkey. Int. Geol. Rev. 1996, 38(9): 838-853.

Temiz, H. Tectonostratigraphy and thrust tectonics of the central and eastern parts of the Sivas Tertiary basin, Turkey. Int. Geol. Rev. 1996, 38(10): 957-971.

Tissot, B.P., Welte, D.H. Petroleum Formation and Occurrence. Berlin, Germany, Springer Berlin Heidelberg, 1984.

Yalçin Erik, N., Aydemir, A., Büyüksaraç, A. Investigation of the organic matter properties and hydrocarbon potential of the Sivas Basin, Central Eastern Anatolia, Turkey, using Rock-Eval data and organic petrography. J. Pet. Sci. Eng. 2015, 127: 148-168.

Yılmaz, A., Yılmaz, H. Characteristic features and structural evolution of a post collisional basin: The Sivas Basin, Central Anatolia, Turkey. J. Asian Earth Sci. 2006, 27(2): 164-176. 